\title{
Influence of Various Levels and Application Methods of Sulphur and Zinc on Nodulation, Quality and Nutrient Content of Chickpea (Cicer arietinum L.)
}

\author{
Deepti Yadav* and H. S. Kushwaha
}

Department of Natural Resourse Management, Faculty of Agriculture, Mahatma Gandhi Chitrakoot Gramodaya Vishwavidyalaya, Chitrakoot, Satna, (M.P.) 485334, India

*Corresponding author

\section{A B S T R A C T}

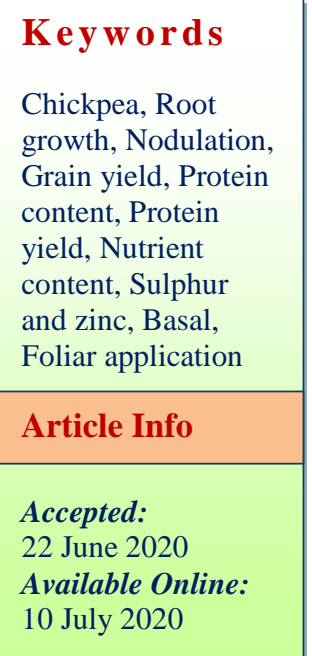

\section{Keywords}

Chickpea, Root content, Protein yield, Nutrient content, Sulphur and zinc, Basal,

\section{Article Info}

Accepted:

22 June 2020 10 July 2020
A field experiment was conducted during rabi season 2007-08 and 2008-09 at Agricultural farm of Mahatma Gandhi Chitrakoot Gramodaya Vishwavidyalaya, Chitrakoot, Satna (M.P.) to study the root growth, nodulation and nutrient content of chickpea. Results revealed that root growth viz. root length, root dry weight/plant; nodulation viz. no. of nodules/plant, nodules dry weight/plant and seed yield were recorded significantly superior under basal application of sulphur $40 \mathrm{~kg} / \mathrm{ha}$ and zinc $5 \mathrm{~kg} / \mathrm{ha}$ during two years. Spray of zinc $0.5 \%$ and sulphur $2 \%$ produced significant greater grain yield over control during two respective years. The protein content of seed and protein yield was observed significantly more under basal application of sulphur $40 \mathrm{~kg} / \mathrm{ha}$ and zinc $5 \mathrm{~kg} / \mathrm{ha}$ during two years. However, foliar application of zinc $0.5 \%$ noted numerically higher protein content of seed while, protein yield was observed significantly higher under foliar spray of zinc $0.5 \%$ over S spray $2 \%$ and control. Sulphur and zinc content in grain were significantly improved with application of sulphur and recorded maximum under $40 \mathrm{~kg} \mathrm{~S} / \mathrm{ha}$ however, basal application of zinc $5 \mathrm{~kg} /$ ha recorded significantly higher $\mathrm{Zn}$ content in grain. Basal application of $40 \mathrm{~kg} \mathrm{~S} / \mathrm{ha}$ observed significantly superior sulphur and zinc content in soil however, $\mathrm{S}$ and $\mathrm{Zn}$ content in soil was significantly improved due to application of zinc 5 $\mathrm{kg} / \mathrm{ha}$. Foliar spray of S $2 \%$ observed significantly higher $\mathrm{S}$ in grain and soil, while $\mathrm{Zn}$ spray $0.5 \%$ recorded more $\mathrm{Zn}$ content in grain and soil.

\section{Introduction}

Chickpea (Cicer arietinum L.) is a premier rabi legume crop in India. It is grown in India of 10.56 million hectares areas and production of 11.23 million tonnes with productivity of 1063 kg/ha (Anonymous, 2018-19). Chickpea being a legume crop has got capacity of fixing nitrogen through Rhizobium bacteria which forms nodules on the roots for this crop. Rhizobium can fix $\mathrm{N}_{2}$ nitrogen actively only if plant is adequately supplied with all mineral elements essential for active growth. In this respect elements like $\mathrm{P}, \mathrm{Ca}, \mathrm{S}, \mathrm{Mo}, \mathrm{Zn}, \mathrm{Fe}, \mathrm{Co}$ and B play an important role (Shubba rao, 1997). The supplementation of secondary like suphur and micronutrient like zinc along with Rhizobium in chickpea cultivars may increase 
biological nitrogen fixation and there by its productivity.

Sulphur is considered to be important secondary nutrients, as it synthesizes sulphur containing amino acids. It also helps in synthesis of chlorophyll, nodules formation and growth of Rhizobium bacteria and to produce oxidation system in respiration. Due to crop identification and use of high analysis straight fertilizers, non $\mathrm{S}$ containing pesticides all these leads to deficiency of $S$ in Indian soils. Out of 135 pulses growing districts, sulphur deficiency in 44 districts ranged between $40-60 \%$, where other 43 districts showed 20-40 \% deficiency (Tiwari and Mishra, 2000).

Zinc is an essential micronutrient and reduces toxicity of element like $\mathrm{Fe}$ altered metabolism of $\mathrm{N}, \mathrm{P}, \mathrm{CHO}$ and nucleic acid. It plays an important role in plant nutrition, which is involved in the biosynthesis of the plant hormones and Indole acetic acid (IAA) and it maintains the normal auxin concentration in tissues. It has in a vital role for the synthesis of protein and nucleic acid and helps in the utilization of $\mathrm{N}$ and $\mathrm{P}$ in plants. It also promotes nodulation and $\mathrm{N}$-fixation in leguminous crops. It has been reported that large area under cultivation in India is becoming deficient in $\mathrm{Zn}$. Despite of this fact not much work has been done regarding response of legumes to zinc in India. In pulse growing areas, the needs of zinc is increasing due to there continues depletion in the soil. Several workers reported the response of $\mathrm{Zn}$ from 2 to $20 \mathrm{~kg} / \mathrm{ha}$ in the different parts of India to pulse crops like gram, green gram, soybean and Pigeon pea (Ali et al., 2005).

An adequate supply of sulphur and zinc may lead to higher productivity of chickpea. Thus to maintain soil health, application of sulphur and zinc need to be standardised. Therefore, keeping this view, the studies were carried out to study the basal and foliar application of sulphur and zinc on root growth, nodulation and sulphur and zinc content of chickpea.

\section{Materials and Methods}

The study was conducted at the Agriculture Farm Rajaula of Mahatma Gandhi Chitrakoot Gramodaya Vishwa Vidyalaya, Chitrakoot, Satna (M.P.) during the rabi season of 200708 and 2008-09. The soil of experimental field was sandy loam with neutral in soil $\mathrm{pH}$ (7.4 and 7.5) and low in organic carbon (0.23 and $0.47 \%$ ) and available $\mathrm{N}(103$ and $198 \mathrm{~kg}$ $\mathrm{N} / \mathrm{ha}$ ), medium to high phosphorus (24.35 and $28.1 \mathrm{~kg} \mathrm{P} / \mathrm{ha}$ ), medium in potassium (124 and $228 \mathrm{~kg} \mathrm{~K} / \mathrm{ha}$ ), sulphur with 47.16 and 52.68 $\mathrm{kg} \mathrm{S} / \mathrm{ha}$ and zinc 2.14 and $2.28 \mathrm{~kg} \mathrm{Zn} / \mathrm{ha}$ during two respective years. The experiment consisted three levels of sulphur $(0,20,40 \mathrm{~kg}$ $\mathrm{S} / \mathrm{ha})$, two levels of zinc $(0,5 \mathrm{~kg} \mathrm{Z} / \mathrm{ha})$ and three levels of foliar spray (water spray, sulphur $2.0 \%$, zinc $0.5 \%$ ). In all 18 treatments will be tested in RBD (factorial) with three replications. An uniform doses of NPK @ 20: 40: 20 kg N $2: \mathrm{P}_{2} \mathrm{O}_{5}: \mathrm{K}_{2} \mathrm{O} /$ ha were applied as basal. Sulphur and zinc were applied as per treatment. However, foliar spray was done at initiation of flower and ten days after first spray. The chickpea variety Uday was sown on $11^{\text {th }}$ Oct 2007 and $27^{\text {th }}$ Sep 2008 in two respective years at a row spacing of $30 \mathrm{~cm}$ apart using seed rate $100 \mathrm{~kg} / \mathrm{ha}$. The plant to plant spacing was maintained $05 \mathrm{~cm}$ by thinning at 20 DAS. Crop was protected from weeds by using one hand weeding at 30 DAS. However, insect pest was controlled by spraying of Dimethoate @ $2 \mathrm{ml} /$ litre water at pod formation stage. The crop was harvested on $25^{\text {th }}$ March 2008 and $10^{\text {th }}$ March 2009 in two respective years. The important growth parameters, yield attributes and yield were recorded at appropriate time as per standard procedure. Zinc was estimated by DTPA extractable zinc (Lindsay and Norvell 1978) with the help of Atomic Absorption 
Spectrophotometer. Protein content in seed was estimated after the estimation of nitrogen percentage in seed by Kjeldhal method with the help of following formula:

Protein content $(\%)=$ Nitrogen content $(\%) X$ 6.25 .

The experimental data was statistically analysed by Panse and Sukhatme (1985). The treatment differences were tested by using "F" test and critical differences at 5\% probability.

\section{Results and Discussion}

\section{Root Growth}

Root length and root dry weight was obtained significantly higher under sulphur $40 \mathrm{~kg} / \mathrm{ha}$ over control and $20 \mathrm{~kg} \mathrm{~S} / \mathrm{ha}$ during 2007-08 and 2008-09. However, application of zinc 5 $\mathrm{kg} / \mathrm{ha}$ recorded significantly superior root length and root dry weight than that of control during two years (Table 1). While, sulphur and zinc spray did not show any significant effect on these growth characters over water spray. The superior root growth might be due to basal application of sulphur and zinc which was associated with shoot parameters.

\section{Root Nodulation}

The formation of root nodules/ plant and dry weight of root nodules/ plant were observed statistically higher under sulphur $40 \mathrm{~kg} / \mathrm{ha}$ than that of preceding doses at 45 and 60 days stages during two years (Table 1). However, application of zinc $5 \mathrm{~kg} / \mathrm{ha}$ recorded significant superior root nodules/ plant and dry weight of root nodules/ plant at 45 and 60 days stages during 2007-08 and 2008-09. The formation of root nodules/ plant and dry weight of root nodules/ plant were found statistically at par in foliar spray of sulphur and zinc in chickpea. Such improvement in nodules formation might be possibly due to starter dose of sulphur and zinc application along with balance supply of nitrogen and phosphorus helps in establishment of the crop which ultimately leads to extensive development of root nodules and bacteria present in them for fulfilling the need of the crop for nitrogen (Sahu et al., 2002).

\section{Grain yield}

The grain yield of chickpea was significantly increased up to $40 \mathrm{~kg} \mathrm{~S} / \mathrm{ha}$ (1923 and 2051 $\mathrm{kg} / \mathrm{ha}$ ) which showed $446 \mathrm{~kg} / \mathrm{ha}$ and 595 $\mathrm{kg} / \mathrm{ha}$; and $122 \mathrm{~kg} / \mathrm{ha}$ and $138 \mathrm{~kg} / \mathrm{ha}$ higher over control and $20 \mathrm{~kg} \mathrm{~S} / \mathrm{ha}$, respectively during 2007-08 and 2008-09 (Table 2). However, the application of zinc $5 \mathrm{~kg} / \mathrm{ha}$ recorded significant improvement in grain (1839 and $1968 \mathrm{~kg} / \mathrm{ha}$ ) of chickpea than that of no zinc during two respective years. Zinc application@5 kg Zn/ha produced 12.96 percent and 49.84 percent more seed yield compared with control during two respective years. The grain yield of chickpea was significantly increased with the application of zinc $0.5 \%$ (1806 and $1930 \mathrm{~kg} / \mathrm{ha}$ ) and sulphur $2 \%$ (1760 and $1803 \mathrm{~kg} / \mathrm{ha})$ and obtained 10.45 $\%$ and $14.45 \%$ more over control during both the years. The improvement in seed yield by zinc application might be due to increase in synthesis of carbohydrate and protein and their translocation to the sink through efficient physiological activity in plants as evident from physiological parameters like shoot and root growth and yield contributing characters like number of primary and secondary branches, pods per plant, pod length, seeds per pod, seed weight per plant and 100 seeds weight. The results are in accordance with those reported by Puste and Jana (1995). Soil application of fertilizer leads to losses of nutrients in the form of leaching, volatilization and fixation affecting the nutrient use efficiency (Veerabhadrappa and Yeledhalli, 2005). 


\section{Protein content and Protein yield}

The protein content of seed (21.53 and $23.49 \%$ ) and protein yield (415 and 482 $\mathrm{kg} / \mathrm{ha}$ ) was observed significantly more under basal application of sulphur $40 \mathrm{~kg} / \mathrm{ha}$ than that of control and $20 \mathrm{~kg} \mathrm{~S} / \mathrm{ha}$ during both the years (Table 2). This could be ascribed that sulphur is a constituent of three essential amino acids (Cysteine, Cystine and Methionine) which promotes the more accumulation of protein content in grain of chickpea. Sulphur application improved yield and quality of cowpea (Thuan, and Rana, 2010) and mungbean (Ram and Katiyar, 2018).

Zinc application $5 \mathrm{~kg} / \mathrm{ha}$ recorded significant superior protein content of seed (20.82 and $22.80 \%)$ and of protein yield (385 and $450 \mathrm{~kg} / \mathrm{ha}$ ), than that of no zinc application. This might be due to zinc application enhance protein and carbohydrates synthesis and their transportation to the site of seed formation. Similar results were reported by Adsul et al., (2020). Micronutrients application also increased the protein harvest maximum values were recorded $6 \mathrm{~kg} \mathrm{Zn} / \mathrm{ha}$ followed by $1 \mathrm{~kg}$ $\mathrm{Mo} / \mathrm{ha}$ and $0.5 \mathrm{~kg} \mathrm{~B} / \mathrm{ha}$ as compared to no micronutrients application in French bean (Singh et al., 2006). More N uptake by plant resulted in more protein yield in seed. The results of similar kind were also reported by Deo et al., (2002).

Foliar application of zinc $0.5 \%$ noted significantly higher protein content of seed than that of no zinc application (20.99) during 2007-08 and statistically at par in 2007-08. Protein yield was observed significantly higher under foliar spray of zinc 0.5 percent over S spray $2 \%$ and control. Such increase could be ascribed due to more proportionate increase $\mathrm{N}$ content in grain. This possible due to more increase in nitrogenase activity in the root nodules might have increased the $\mathrm{N}$ fixation and there by $\mathrm{N}$ content in grain. The results are in agreement with the findings of Abd EL-Kader and Mona (2013), Alam et al., (1999) and Chandra (1995). In this concern Ved et al., (2002) stated that foliar applied zinc enhances photosynthesis at early growth of mungbean plants, improves their nitrogen fixation, grain protein and yields.

\section{Nutrient content}

\section{Sulphur and zinc content in grain}

The sulphur contents in grain was significantly increased with application of sulphur and it was maximum at $40 \mathrm{~kg} \mathrm{~S} / \mathrm{ha}$ (0.22 and $0.24 \%)$ during 2007-08 and 200809 (Table 3). This might be due to more availability of available $S$ to plant resulted more uptake and S content in grain. Sulphur is a constituent of three essential amino acids (Cysteine, Cystine and Methionine) and also a constituent of ferrodoxin-containing Nitrogenase, which takes part in the biological nitrogen fixation resulting highest number of nodules/ plant and nitrogen and sulphur content in the soil. Similar finding was also reported by Khan and Prakash (2014). This trend was perhaps to establish favourable $\mathrm{N}: \mathrm{S}$ ratio in the vegetative tissue of the plant (Kachhave et al., 1997).

Application of zinc $5 \mathrm{~kg} / \mathrm{ha}$ recorded numerically higher $\mathrm{S}$ content in seed. Foliar spray of S $2 \%$ significantly increased $\mathrm{S}$ content in seed over control and $\mathrm{Zn} 0.5 \%$. Zinc content in grain was significantly increased and obtained superior under $40 \mathrm{~kg}$ S/ha during two years. However, the maximum contents of $\mathrm{Zn}$ in grain (36.94 and $36.08 \mathrm{mg} / \mathrm{kg}$ ) was recorded with application of $5 \mathrm{~kg} \mathrm{Zn} /$ ha during 2006-07 and 2008-09, respectively. Foliar spray of $\mathrm{Zn} 0.5 \%$ conspicuously increased $\mathrm{Zn}$ content over control and S spray 2\%. Similar results have been reported by Bansal (1992) in wheat crop. 
Table.1 Effect of sulphur and zinc as basal and foliar application on root growth and nodulation of chickpea

\begin{tabular}{|c|c|c|c|c|c|c|c|c|c|c|c|c|}
\hline \multirow[t]{3}{*}{ Treatment } & \multirow{2}{*}{\multicolumn{2}{|c|}{$\begin{array}{c}\text { Root length/ } \\
\text { plant }(\mathbf{c m})\end{array}$}} & \multirow{2}{*}{\multicolumn{2}{|c|}{$\begin{array}{c}\begin{array}{c}\text { Root dry } \\
\text { weight/ plant (g) }\end{array} \\
60 \mathrm{DAS}\end{array}$}} & \multicolumn{4}{|c|}{ No. of Nodules/ plant } & \multicolumn{4}{|c|}{ Nodules dry weight/ plant (mg) } \\
\hline & & & & & \multicolumn{2}{|c|}{$45 \mathrm{DAS}$} & \multicolumn{2}{|c|}{$60 \mathrm{DAS}$} & \multicolumn{2}{|c|}{$45 \mathrm{DAS}$} & \multicolumn{2}{|c|}{$60 \mathrm{DAS}$} \\
\hline & $\begin{array}{l}2007- \\
08\end{array}$ & $\begin{array}{l}2008- \\
09\end{array}$ & $\begin{array}{l}2007- \\
08\end{array}$ & $\begin{array}{l}\text { 2008- } \\
09\end{array}$ & $\begin{array}{l}2007- \\
08\end{array}$ & $\begin{array}{l}2008- \\
09\end{array}$ & 2007-08 & 2008-09 & $\begin{array}{l}2007- \\
08\end{array}$ & $\begin{array}{l}2008- \\
09\end{array}$ & $\begin{array}{l}2007- \\
08\end{array}$ & $\begin{array}{l}2008- \\
09\end{array}$ \\
\hline \multicolumn{13}{|c|}{ S Level(kg S /ha) } \\
\hline $\mathbf{0}$ & 11.91 & 12.07 & 0.57 & 1.29 & 8 & 10 & 8 & 11 & 19.15 & 19.37 & 22.81 & 24.46 \\
\hline SE $\mathbf{m} \pm$ & 0.18 & 0.20 & 0.02 & 0.06 & 0.32 & 0.33 & 0.17 & 0.33 & 0.45 & 0.67 & 0.68 & 0.66 \\
\hline $\mathrm{CD}(\mathrm{P}=0.5)$ & 0.51 & 0.58 & 0.05 & 0.17 & 0.93 & 0.95 & 0.50 & 0.94 & 1.28 & 1.94 & 1.95 & 1.91 \\
\hline \multicolumn{13}{|c|}{ Zn level (kg Zn /ha) } \\
\hline $\mathbf{0}$ & 13.35 & 13.24 & 0.63 & 2.12 & 10 & 11 & 11 & 13 & 26.52 & 23.68 & 32.22 & 30.38 \\
\hline 5 & 14.69 & 14.69 & 0.75 & 2.34 & 13 & 17 & 13 & 18 & 31.73 & 33.85 & 38.06 & 41.17 \\
\hline $\begin{array}{l}\text { Water } \\
\text { spray }\end{array}$ & 14.07 & 13.94 & 0.68 & 2.24 & 11 & 14 & 12 & 15 & 27.91 & 28.49 & 32.97 & 35.05 \\
\hline $\begin{array}{ll}\text { S } & \text {-spray } \\
2 \% & \end{array}$ & 14.01 & 13.81 & 0.70 & 2.23 & 12 & 14 & 12 & 16 & 29.26 & 28.79 & 35.29 & 35.60 \\
\hline $\begin{array}{l}\text { Zn spray } \\
0.5 \%\end{array}$ & 13.99 & 14.13 & 0.70 & 2.23 & 12 & 14 & 12 & 16 & 30.20 & 29.01 & 37.16 & 36.68 \\
\hline SE $\mathbf{m} \pm$ & 0.18 & 0.20 & 0.02 & 0.06 & 0.32 & 0.33 & 0.17 & 0.33 & 0.45 & 0.67 & 0.68 & 0.66 \\
\hline $\mathrm{CD}(\mathrm{P}=0.5)$ & NS & NS & NS & NS & NS & NS & NS & NS & 1.28 & NS & NS & NS \\
\hline
\end{tabular}


Table.2 Effect of sulphur and zinc as basal and foliar application on grain yield and quality parameters of chickpea

\begin{tabular}{|c|c|c|c|c|c|c|}
\hline \multirow[t]{2}{*}{ Treatment } & \multicolumn{2}{|c|}{ Seed yield (kg/ ha) } & \multicolumn{2}{|c|}{ Protein content (\%) } & \multicolumn{2}{|c|}{ Protein yield (kg/ ha) } \\
\hline & 2007-08 & 2008-09 & 2007-08 & 2008-09 & 2007-08 & 2008-09 \\
\hline \multicolumn{7}{|l|}{ S Level(kg S /ha) } \\
\hline 0 & 1477 & 1456 & 18.20 & 21.05 & 271 & 308 \\
\hline 20 & 1801 & 1913 & 19.58 & 22.76 & 353 & 435 \\
\hline 40 & 1923 & 2051 & 21.53 & 23.49 & 415 & 482 \\
\hline SE $\mathbf{m} \pm$ & 26.44 & 23.30 & 0.39 & 0.19 & 8.86 & 6.79 \\
\hline $\mathrm{CD}(\mathbf{P}=0.5)$ & 75.99 & 66.98 & 1.13 & 0.56 & 25.46 & 19.54 \\
\hline \multicolumn{7}{|c|}{ Zn level (kg Zn /ha) } \\
\hline 0 & 1628 & 1646 & 18.71 & 22.06 & 308 & 367 \\
\hline 5 & 1839 & 1968 & 20.82 & 22.80 & 385 & 450 \\
\hline SE $\mathbf{m} \pm$ & 21.59 & 19.03 & 0.32 & 0.15 & 7.23 & 5.55 \\
\hline $\mathrm{CD}(\mathrm{P}=0.5)$ & 62.04 & 54.69 & 0.93 & 0.46 & 20.79 & 15.95 \\
\hline \multicolumn{7}{|l|}{ Foliar Spray } \\
\hline Water spray & 1635 & 1687 & 19.23 & 22.28 & 319 & 380 \\
\hline S spray $2 \%$ & 1760 & 1803 & 19.08 & 22.32 & 339 & 406 \\
\hline Zn spray $0.5 \%$ & 1806 & 1930 & 20.99 & 22.69 & 381 & 440 \\
\hline SE $\mathbf{m} \pm$ & 26.44 & 23.30 & 0.39 & 0.19 & 8.86 & 6.79 \\
\hline $\mathrm{CD}(\mathrm{P}=0.5)$ & 75.99 & 66.98 & 1.13 & NS & 25.46 & 19.54 \\
\hline
\end{tabular}

Table.3 Effect of sulphur and zinc as basal and foliar application on contents of sulphur and zinc in grain and soil

\begin{tabular}{|c|c|c|c|c|c|c|c|c|}
\hline \multirow[t]{2}{*}{ Treatment } & \multicolumn{2}{|c|}{$S$ content in grain $(\%)$} & \multicolumn{2}{|c|}{$\begin{array}{c}\text { Zn content in grain } \\
(\mathrm{mg} / \mathrm{kg})\end{array}$} & \multicolumn{2}{|c|}{$\begin{array}{c}S \text { content in soil } \\
(\mathrm{mg} / \mathrm{kg})\end{array}$} & \multicolumn{2}{|c|}{$\begin{array}{c}\text { Zn content in soil } \\
(\mathrm{mg} / \mathrm{kg})\end{array}$} \\
\hline & 2007-08 & 2008-09 & 2007-08 & 2008-09 & 2007-08 & 2008-09 & 2007-08 & 2008-09 \\
\hline \multicolumn{9}{|c|}{ S Level (kg S /ha) } \\
\hline 0 & 0.18 & 0.18 & 32.57 & 32.71 & 6.54 & 6.60 & 0.56 & 0.60 \\
\hline 20 & 0.21 & 0.23 & 33.60 & 33.14 & 11.23 & 11.74 & 0.60 & 0.62 \\
\hline 40 & 0.22 & 0.24 & 36.17 & 35.90 & 20.61 & 21.89 & 0.68 & 0.69 \\
\hline SE $\mathbf{m} \pm$ & 0.01 & 0.004 & 0.79 & 0.61 & 0.24 & 0.18 & 0.01 & 0.01 \\
\hline $\mathrm{CD}(\mathbf{P}=\mathbf{0 . 5})$ & 0.02 & 0.01 & 2.26 & 1.77 & 0.68 & 0.53 & 0.03 & 0.03 \\
\hline \multicolumn{9}{|c|}{ Zn level (kg Zn /ha) } \\
\hline 0 & 0.20 & 0.21 & 31.29 & 31.75 & 12.62 & 12.98 & 0.45 & 0.49 \\
\hline 5 & 0.21 & 0.22 & 36.94 & 36.08 & 12.96 & 13.83 & 0.78 & 0.78 \\
\hline SE $\mathbf{m} \pm$ & 0.005 & 0.003 & 0.64 & 0.50 & 0.19 & 0.15 & 0.01 & 0.01 \\
\hline $\mathrm{CD}(\mathrm{P}=0.5)$ & NS & 0.01 & 1.85 & 1.44 & 0.56 & 0.43 & 0.02 & 0.03 \\
\hline \multicolumn{9}{|l|}{ Foliar Spray } \\
\hline $\begin{array}{l}\text { Water } \\
\text { spray }\end{array}$ & 0.19 & 0.21 & 32.80 & 32.19 & 12.70 & 13.34 & 0.55 & 0.57 \\
\hline S\% - spray & 0.23 & 0.23 & 34.01 & 33.27 & 13.72 & 14.24 & 0.55 & 0.60 \\
\hline $\begin{array}{l}\text { Zn - spray } \\
0.5 \%\end{array}$ & 0.19 & 0.21 & 35.54 & 36.29 & 11.96 & 12.64 & 0.75 & 0.75 \\
\hline SE $\mathbf{m} \pm$ & 0.01 & 0.004 & 0.79 & 0.61 & 0.24 & 0.18 & 0.01 & 0.01 \\
\hline $\mathrm{CD}(\mathbf{P}=\mathbf{0 . 5})$ & 0.02 & 0.01 & NS & 1.77 & 0.68 & 0.53 & 0.03 & 0.03 \\
\hline
\end{tabular}


Increased availability of $\mathrm{Zn}$ in the soil on the addition of water soluble EDTA $\mathrm{Zn}$ resulted in increase in its contents in the grains. Increased availability of $\mathrm{Zn}$ in the soil on the addition of water soluble $\mathrm{ZnCl}_{2}$ resulted in increase in its contents in the grains. Similar findings have also been reported by Tripathi et al., (1997) and Dev et al., (1992).

\section{Sulphur and zinc content in soil}

Sulphur (20.61 and $21.89 \mathrm{mg} / \mathrm{kg}$ ) and zinc contents $(0.68$ and $0.69 \mathrm{mg} / \mathrm{kg})$ in soil after harvest of crop were found significantly higher in $40 \mathrm{~kg} \mathrm{~S} /$ ha over control and $20 \mathrm{~kg}$ S/ha during both the years (Table 3). However, addition of $5 \mathrm{~kg} \mathrm{Zn/ha} \mathrm{recorded}$ significantly superior sulphur (12.96 and $13.83 \mathrm{mg} / \mathrm{kg}$ ) and $\mathrm{Zn}$ contents (0.78 and 0.78 $\mathrm{mg} / \mathrm{kg}$ ) in soil during 2007-08 and 2008-09, respectively. Foliar spray of S $2 \%$ increased S content in soil however, zinc spray 0.5 enhanced Zn content in soil. The increase in $S$ and $\mathrm{Zn}$ content in soil might be due drifted particles of sulphur or zinc spray on the soil. In case of greater bioavailability of the grain zinc derived from foliar applications than from soil, agronomic biofortification would be a very attractive and useful strategy in solving zinc deficiency related health problems globally and effectively (Yosefi1 et al., 2011; Abd El-Baky et al., 2010; Cakmak, 2008)

Thus, it can be concluded that sulphur 40 $\mathrm{kg} / \mathrm{ha}$ and zinc $5 \mathrm{~kg} / \mathrm{ha}$ application were found equally most effective in respect of root growth, nodulation, yield, quality and $S$ and Zn content in grain of chickpea and for soil status of $\mathrm{S}$ and $\mathrm{Zn}$. Foliar applications of $\mathrm{S}$ $2 \%$ and $\mathrm{Zn} 0.5 \%$ are more suitable than the soil application due to the rapid overcoming on deficiency, easy to use, reduce the toxicity caused by accumulation and prevent of elements stabilization in the soil.

\section{References}

Abd El-Baky, M.M.H., Ahmed, A.A., ElNemr, M.A. and Zaki, M.F., (2010). Effect of potassium fertilizer and foliar zinc application on yield and quality of sweet potato. Research Journal of Agriculture and Biological Science 6(4): 386-394.

Kader, Abd EL and Mona, G. (2013). Effect of Sulfur Application and Foliar Spraying with Zinc and Boron on Yield, Yield Components, and Seed Quality of Peanut (Arachis hypogaea L.). Research Journal of Agriculture and Biological Sciences 9(4):127-135.

Adsul, P.B., Patil, V.D. and Shinde, S.E. (2020). Effect of soil application of sulphur and zinc and foliar application of $\mathrm{KNO}_{3}$, Borax, NAA and GA on chlorophyll, carotenoid and quality parameters of soybean (Glycine max L. Merrill). Journal of Pharmacognosy and Phytochemistry 9(3): 494-497.

Alam, M. J., Solaiman, A. R. M and Karim, A. J. M. S. (1999). Nutrient uptake, yield, yield attributes and protein content of chickpea as influenced by some Rhizobium strains. Annals of Bangladesh Agriculture 9(2): 131-138.

Ali, M., Krishnamurthy, L., Saxena, N.P., Rupela, O.P., Kumar, J. and Johansen, C. (2005). Scope for genetic manipulation of mineral acquisition in chickpea. Plant and Soil 245(1): 123134.

Anonymous (2018-19). Agriculture statistics at a Glance. Department of Agriculture and Cooperation, Ministry of Agriculture and Farmers Welfare, Government of India.

Bansal, K.N. (1992). Effect of applied sulphur on $\mathrm{S}$ and $\mathrm{N}$ fraction and critical limit of $\mathrm{S}$ in wheat plant. Journal of the Indian Society of Soil Science. 40:92-96.

Cakmak, I., (2008). Enrichment of cereal 
grains with zinc: Agronomic or genetic biofortification. Plant and Soil. 302:117.

Chandra, R. (1995). Response and economics of Rhizobium, phosphorus and zinc application in gram in Western U.P. Plains. Legume Research 18(2): 103108

Deo, C., Kothari, M.L. and Kalra, Y.P. (2002). Effect of nodes and levels of Mo application on grain yield, protein content and nodulation of chickpea grown on sandy loam soil. Soil Science Plant Analysis 33(15-18): 2905-2915.

Dev, S., Gupta, S.P., and Singh, J.P. (1992). Response or Pigeonpea to Zinc Application as Inftuenced by Genotypic Variability. Journal of the Indian Society of Soil Science. 40:218219.

Kachhave, K.G., Gawande, S.D., Kohire, O.D. and Mane, S.S. (1997). Influence of Various Sources and Levels of Sulphur on Nodulation, Yield of and Uptake of Nutrients by Chickpea. Journal of the Indian Society of Soil Science 45(3): 590-591.

Khan, Khalil and Prakash, Ved (2014). Effect of rhizobial inoculation on growth, yield, nutrient and economics of summer urdbean (Vigna mungo L.) in relation to zinc and molybdnum. Journal of Food Legume 27:261-263.

Panse, V.G. and Sukhatme, P. V. (1985). Randomized Block and Latin square designs. Statistical Methods for Agricultural Workers, ICAR, New Delhi. pp. 152-165.

Puste, A.M. and Jana, P.K. (1995). Effect of $\mathrm{P}_{2} \mathrm{O}_{5}$ and zinc on the yield attributes and yield of pigeonpea varieties grown during winter season. Madras Agricultural Journal. 82(5): 348-351.

Ram, Surendra and Katiyar, T.P.S. (2018).Response of sulphur and zinc on yield, quality and nutrient uptake of summer mungbean (Vigna radiata L. Wilczek). Journal of Pharmacognosy and Phytochemistry 2018(SP1): 32433245.

Sahu, J.P., Singh, N.P., Kaushik, M.K., Sharma, B.B. and Singh, V.K. (2002). Effect of Rhizobium, phosphorus and potash application on the productivity of lentil. Indian Journal of Pulses Research 15(1): 39-42.

Singh, R. K., Singh, J., De, Nirmal and Rai, M. (2006). Effect of nutrient on yield and root parameters in vegetable pea. Vegetable Science 33(1): 88-90.

Subba Rao, N.S.(1997). Soil Microorganism and Plant Growth. pp. 96.

Thuan, N.T.Q. and Rana, D.S. (2010). Productivity and response to sulphur of quality cowpea (Vigna unguiculata) sequence under different sources of nutrients and sulphur levels. Indian Journal of Agronomy 55(4): 264-269.

Tiwari, R.C. and Mishra, A.K. (2000). Extended Summary, International Conference on Managing Natural Resources for Sustainable Agricultural Production in the $21^{\text {st }}$ Century New Delhi.

Tripathi, H. C.; Singh, R. S. and Mishra, V.K. (1997). Effect of S and Zn nutrition on yield and quality of chickpea (Cicer arietinum L.). Journal of the Indian Society of Soil Science. 45 (1): 123126.

Ved, R., Misra, S.K. and Upadhyay, R.M. (2002). Effects of sulphur, zinc and biofertilizers on the quality characteristics of mungbean. Indian Journal of Pulses Research 2: 139-141. Veerabhadrappa, B.H. and Yeledhalli, N.A. (2005). Effect of Soil and Foliar Application of Nutrients on Growth and Yield of Groundnut. Karnataka Journal of Agriculture Science. 18 (3): 814-816. 
Yosefi, K., Galavi, M., Ramrodi M. and Mousavi, S.R. (2011). Effect of biophosphate and chemical phosphorus fertilizer accompanied with micronutrient foliar application on growth, yield and yield components of maize (Single Cross 704). Australian Journal of Crop Science 5(2):175-180.

\section{How to cite this article:}

Deepti Yadav and Kushwaha, H. S. 2020. Influence of Various Levels and Application Methods of Sulphur and Zinc on Nodulation, Quality and Nutrient Content of Chickpea (Cicer arietinum L.). Int.J.Curr.Microbiol.App.Sci. 9(07): 3971-3979.

doi: https://doi.org/10.20546/ijcmas.2020.907.466 